\title{
Investigation of the serum oxidative stress in broilers fed on diets supplemented with nickel chloride
}

\author{
Bangyuan Wu, Hengmin Cui*, Xi Peng, Jing Fang, Zhicai Zuo, Junliang Deng, Jianying Huang
}

Key Laboratory of Animal Diseases and Environmental Hazards of Sichuan Province, College of Veterinary Medicine, Sichuan Agricultural University, Ya'an, China; ${ }^{*}$ Corresponding Author: cui580420@,sicau.edu.cn; cuihengmin2008@,sina.com

Received 15 January 2013; revised 15 February 2013; accepted 25 February 2013

\begin{abstract}
The purpose of this study was to investigate the serum oxidative stress induced by dietary nickel chloride $\left(\mathrm{NiCl}_{2}\right)$ in broilers. A total of 240 oneday-old avian broilers were divided into four groups and fed on a corn-soybean basal diet as control diet or the same basal diet supplemented with $300 \mathrm{mg} / \mathrm{kg}, 600 \mathrm{mg} / \mathrm{kg}$ and 900 $\mathrm{mg} / \mathrm{kg} \mathrm{NiCl}{ }_{2}$. During the experimental period of 42 days, oxidative stress parameters were determined for both control and experimental groups. The results showed that malondialdehyde (MDA) content was significantly higher $(p<$ 0.05 or $p<0.01$ ) in the $300 \mathrm{mg} / \mathrm{kg}, 600 \mathrm{mg} / \mathrm{kg}$ and $900 \mathrm{mg} / \mathrm{kg}$ groups than that in the control group. In contrast, the activities of superoxide dismutase (SOD), catalase (CAT) and glutathione peroxidase (GSH-Px), and the ability to inhibit hydroxy radical, and glutathione hormone (GSH) content were significantly decreased $(p<0.05$ or $p<0.01$ ) in the $300 \mathrm{mg} / \mathrm{kg}, 600 \mathrm{mg} / \mathrm{kg}$ and 900 $\mathrm{mg} / \mathrm{kg}$ groups in comparison with those of the control group. It was concluded that dietary $\mathrm{NiCl}_{2}$ in excess of $300 \mathrm{mg} / \mathrm{kg}$ could cause oxidative stress, which could finally impaired the antioxidant function in broilers.
\end{abstract}

Keywords: Broiler; Nickel Chloride; Oxidative Stress; Serum

\section{INTRODUCTION}

Nickel (Ni) is the $5^{\text {th }}$ most abundant element by weight after iron, oxygen, magnesium and silicon. And $\mathrm{Ni}$ is a naturally occurring element that can exist in various mineral forms and is used widely in the metallurgical, chemical and food processing industries, especially as catalysts and pigments [1]. The $\mathrm{Ni}$ salts of greatest commercial importance are nickel chloride $\left(\mathrm{NiCl}_{2}\right)$, sulphate, nitrate, carbonate, hydroxide, acetate and oxide
$[1,2]$. The essentiality of $\mathrm{Ni}$ in the nutrition of different classes of animals (including rats, pigs, goats and chicks and so on) has been demonstrated [3-6]. Ni is involved in methionine-folate metabolism [7-9], and is a composition of catalytically active hydrogenase protein [10] or might be part of a regulatory component [11]. Ni ions a higher affinity for proteins and amino acids and have shown to produce oxidation of proteins in cells [12]. Binding of $\mathrm{Ni}$ to some chromatin proteins in somatic cells may result in oxidative and structural damage to proteins [13]. It has been reported that $\mathrm{Ni}$ may have a role in the hormone action and in the regulation of the prolactin secretion $[14,15]$. Ni deprivation in rats can cause depressed growth, reduced reproductive rates, decreased sperm count and motility, and alterations of serum lipids and glucose [16], and also raise increased neonatal mortality, uneven hair development in pups, and result in ultrastructural changes and decreased cholesterol contents in the liver of the successive generations [4]. In addition, $\mathrm{Ni}$ is a nutritionally essential trace metal for micro-organisms and plants [17]. Currently, eight Nicontaining enzymes have been identified [18].

It has been reported that chemical substances (such as Ni) spread along a large area through wind, rain and so on, and are accumulated on plants, animals and soil, and can affect human health badly [19]. Higher quantity of $\mathrm{Ni}$ creates allergy, cancer, non malignant respiratory tract disorders and iatrogenic Ni poisoning, and may cause toxic effects in the immune system [20]. Also, Ni may bind to DNA-repair enzymes and generate oxygen-free radicals in various tissues in both human and animals, and enhance lipid peroxidation and finally cause protein degradation [21]. Free radical generation from the reaction of Ni-thiol complexes and molecular oxygen, and/or lipid hydroperoxides, could play an important role in the mechanism(s) of Ni toxicity [22].

However, there is no relevant research about the impact of $\mathrm{NiCl}_{2}$ on the oxidative stress in the serum of broilers. The purpose of this study was to investigate the effects of dietary $\mathrm{NiCl}_{2}$ on the oxidative stress and antioxidant function in the serum of broilers. Parameters 
used to represent the oxidative stress in this study included the activities of superoxide dismutase (SOD), catalase (CAT) and glutathione peroxidase (GSH-Px), and the ability to inhibit hydroxy radical, and contents of glutathione hormone (GSH) and malondialdehyde (MDA).

\section{MATERIALS AND METHODS}

\subsection{Chickens and Diets}

240 one-day-old healthy avian broilers were randomly divided into four groups with 60 broilers in each group. Broilers were housed in cages with electrically heated units and were provided with water as well as undermentioned experimental diets ad libitum for 42 days.

A corn-soybean basal diet formulated by the National Research Council (NRC) [23] was the control diet. $\mathrm{NiCl}_{2} \cdot 6 \mathrm{H}_{2} \mathrm{O}$ was mixed into the corn-soybean basal diet to produce experimental diets containing $300 \mathrm{mg} / \mathrm{kg}, 600$ $\mathrm{mg} / \mathrm{kg}$ and $900 \mathrm{mg} / \mathrm{kg}$ of $\mathrm{NiCl}_{2}$, respectively (Table 1). The references minimal and maximal concentration were used as Capcarova et al. introduced [24].

All experimental procedure involving animals were

Table 1. Composition of the basal diets for broilers (\%).

\begin{tabular}{|c|c|c|c|c|}
\hline Ingredient $^{1}(\%)$ & $\begin{array}{l}\text { Control } \\
\text { group }\end{array}$ & $\begin{array}{c}300 \mathrm{mg} / \mathrm{kg} \\
\text { group }\end{array}$ & $\begin{array}{c}600 \mathrm{mg} / \mathrm{kg} \\
\text { group }\end{array}$ & $\begin{array}{c}900 \mathrm{mg} / \mathrm{kg} \\
\text { group }\end{array}$ \\
\hline Ground yellow corn & 54.85 & 54.85 & 54.85 & 54.85 \\
\hline Soybean meal & 36.70 & 36.70 & 36.70 & 36.70 \\
\hline Soybean oil & 3.99 & 3.99 & 3.99 & 3.99 \\
\hline Ground limestone & 1.30 & 1.30 & 1.30 & 1.30 \\
\hline Dicalcium phosphate & 1.85 & 1.85 & 1.85 & 1.85 \\
\hline Salt & 0.40 & 0.40 & 0.40 & 0.40 \\
\hline Choline Chloride & 0.18 & 0.18 & 0.18 & 0.18 \\
\hline DL-Met & 0.20 & 0.20 & 0.20 & 0.20 \\
\hline Multi-vitamins & 0.03 & 0.03 & 0.03 & 0.03 \\
\hline Micronutrients $^{2}$ & 0.50 & 0.50 & 0.50 & 0.50 \\
\hline $\begin{array}{l}\text { Nickel Chloride } \\
(\mathrm{mg} / \mathrm{kg})\end{array}$ & 0.00 & 300.00 & 600.00 & 900.00 \\
\hline \multicolumn{5}{|c|}{ Calculated Nutrients level (\%) } \\
\hline $\mathrm{ME}, \mathrm{MJ} / \mathrm{kg}$ & 3.02 & 3.02 & 3.02 & 3.02 \\
\hline $\mathrm{CP}$ & 20.50 & 20.50 & 20.50 & 20.50 \\
\hline Lys & 1.11 & 1.11 & 1.11 & 1.11 \\
\hline Met+Cys & 0.80 & 0.80 & 0.80 & 0.80 \\
\hline $\mathrm{Ca}$ & 1.02 & 1.02 & 1.02 & 1.02 \\
\hline Nonphytate P & 0.42 & 0.42 & 0.42 & 0.42 \\
\hline
\end{tabular}

${ }^{1}$ Ingredient and nutrient composition are reported on as-fed basis. ${ }^{2}$ For the diet of d $1-42$, provided per kilogram of diet: vitamin A (all-trans retinol acetate), 12,500 IU; cholecalciferol, $2500 \mathrm{IU}$; vitamin E (all-rac- $\alpha$-tocopherol acetate), $18.75 \mathrm{IU}$; vitamin $\mathrm{K}$ (menadione $\mathrm{Na}$ bisulfate), $5.0 \mathrm{mg}$; thiamin (thiamin mononitrate), $2.5 \mathrm{mg}$; riboflavin, $7.5 \mathrm{mg}$; vitamin $\mathrm{B}_{6}, 5.0$ $\mathrm{mg}$; vitamin $\mathrm{B}_{12}, 0.0025 \mathrm{mg}$; pantothenate, $15 \mathrm{mg}$; niacin, $50 \mathrm{mg}$; folic acid,

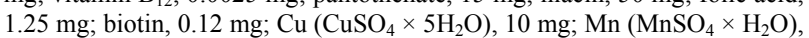
$100 \mathrm{mg} ; \mathrm{Zn}\left(\mathrm{ZnSO}_{4} \times 7 \mathrm{H}_{2} \mathrm{O}\right), 100 \mathrm{mg} ; \mathrm{Fe}\left(\mathrm{FeSO}_{4} \times 7 \mathrm{H}_{2} \mathrm{O}\right), 100 \mathrm{mg} ; \mathrm{I}(\mathrm{KI})$, $0.4 \mathrm{mg} ; \mathrm{Se}\left(\mathrm{Na}_{2} \mathrm{SeO}_{3}\right), 0.2 \mathrm{mg}$. approved by Sichuan Agricultural University Animal Care and Use Committee.

\subsection{Sample Preparation}

5 broilers in each group were phlebotomized from the jugular vein at 14, 28, and 42 days of age during the experiment. Blood was clotted for $15 \mathrm{~min}$ and then centrifugated for $15 \mathrm{~min}$ at the speed of $3000 \mathrm{r} / \mathrm{min}$. The serum was removed and assayed immediately.

\subsection{Detection of Oxidative Stress Parameters in the Serum}

The activities of SOD, CAT and GSH-Px, and ability to inhibit hydroxy radical, and contents of MDA and GSH in the serum were detected by biochemical methods following the instruction of the reagent kits (SOD: Cat.No.: A001-1, LOT: 20120625; CAT: Cat.No.: A007, LOT: 20120629; GSH-Px: Cat.No.: A005, LOT: 20120625; abilities to inhibit hydroxy radical: Cat.No.: A018, LOT: 20120624; MDA: Cat.No.: A003-1, LOT: 20120413; GSH: Cat.No.: A006, LOT: 20120629) which were purchased from Nanjing Jiancheng Bioengineering Institute of China. The absorbance of SOD, CAT, GSHPx, abilities to inhibit hydroxy radical, MDA and GSH were measured at 550, 240, 412, 550, 532 and $420 \mathrm{~nm}$, respectively using a microtiter plate reader (Thermo, Varioskan Flash, USA).

\subsection{Statistical Analysis}

The significance of difference among four groups was analyzed by variance analysis, and results presented as means \pm standard deviation $(\mathrm{X} \pm \mathrm{S})$. The analysis was performed under SPSS 12.0 for windows. A value of $\mathrm{p}<$ 0.05 was considered significant.

\section{RESULTS}

\subsection{Changes of the SOD Activities}

The results were shown in Figure 1. The serum SOD activities were lower $(\mathrm{p}<0.05)$ in the $600 \mathrm{mg} / \mathrm{kg}$ and $900 \mathrm{mg} / \mathrm{kg}$ groups than those in the control group at the 28 days of age, and were significantly lower $(p<0.05$ or $\mathrm{p}<0.01$ ) in the $300 \mathrm{mg} / \mathrm{kg}, 600 \mathrm{mg} / \mathrm{kg}$ and $900 \mathrm{mg} / \mathrm{kg}$ groups than those in the control group at the 42 days of age.

\subsection{Changes of the CAT Activities}

The serum CAT activities were reduced $(\mathrm{p}<0.05)$ in the $900 \mathrm{mg} / \mathrm{kg}$ group at 28 days of age when compared with those of the control group, and were significantly lower $(\mathrm{p}<0.05$ or $\mathrm{p}<0.01)$ in the $300 \mathrm{mg} / \mathrm{kg}, 600 \mathrm{mg} / \mathrm{kg}$ and $900 \mathrm{mg} / \mathrm{kg}$ groups than those in the control group at 42 days of age, which was shown in Figure 2. 


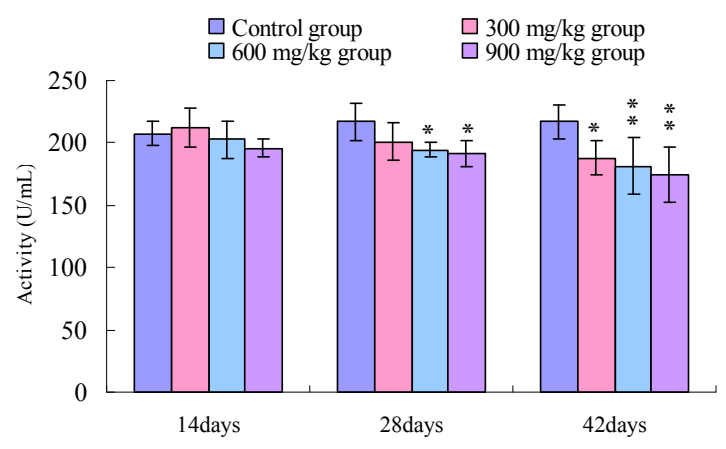

Figure 1. Change of the serum SOD activity $(\mathrm{U} / \mathrm{mL})$ in broilers. Note: Data are presented with the means \pm standard deviation $(\mathrm{n}=5) ;{ }^{*} \mathrm{p}<0.05$, compared with the control group; ${ }^{* *} \mathrm{p}<0.01$, compared with the control group.

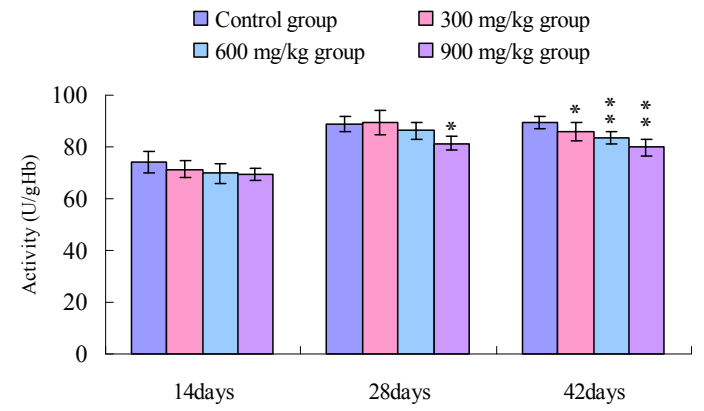

Figure 2. Change of the serum CAT activity (U/gHb) in broilers. Note: Data are presented with the means \pm standard deviation $(\mathrm{n}=5) ;{ }^{*} \mathrm{p}<0.05$, compared with the control group; ${ }^{* *} \mathrm{p}<0.01$, compared with the control group.

\subsection{Changes of the GSH-Px Activities}

As shown in Figure 3, the serum GSH-Px activities were lower $(\mathrm{p}<0.05)$ in the $900 \mathrm{mg} / \mathrm{kg}$ group at 14 days of age, and significantly lower ( $<<0.05$ or $p<0.01)$ in the $300 \mathrm{mg} / \mathrm{kg}, 600 \mathrm{mg} / \mathrm{kg}$ and $900 \mathrm{mg} / \mathrm{kg}$ groups than those in the control group from 28 to 42 days of age.

\subsection{Change of the Ability to Inhibit Hydroxy Radical}

The results in Figure 4 showed that the ability to inhibit hydroxy radical in the serum was reduced $(\mathrm{p}<0.05)$ in the $600 \mathrm{mg} / \mathrm{kg}$ and $900 \mathrm{mg} / \mathrm{kg}$ group when compared with that of the control group at 14 days of age, and was significantly decreased $(\mathrm{p}<0.05$ or $\mathrm{p}<0.01)$ in the 300 $\mathrm{mg} / \mathrm{kg}, 600 \mathrm{mg} / \mathrm{kg}$ and $900 \mathrm{mg} / \mathrm{kg}$ groups than that in the control group from 28 to 42 days of age.

\subsection{Changes of the GSH Contents}

The GSH contents were reduced $(p<0.05)$ in the 900 $\mathrm{mg} / \mathrm{kg}$ group at 14 days of age, and were decreased ( $<<$ 0.05 ) in the $600 \mathrm{mg} / \mathrm{kg}$ and $900 \mathrm{mg} / \mathrm{kg}$ groups at 28 days of age, and were significantly reduced ( $\mathrm{p}<0.05$ or $\mathrm{p}<$ 0.01 ) in the $300 \mathrm{mg} / \mathrm{kg}, 600 \mathrm{mg} / \mathrm{kg}$ and $900 \mathrm{mg} / \mathrm{kg}$ groups at the 42 days of age when compared with those of control group. The results were shown in Figure 5.

\subsection{Changes of the MDA Contents}

The results in Figure 6 showed that the serum MDA

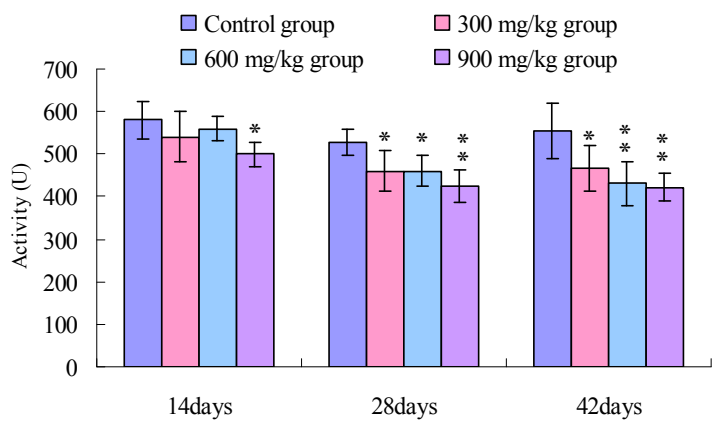

Figure 3. Change of the serum GSH-Px activity (U) in broilers. Note: Data are presented with the means \pm standard deviation $(\mathrm{n}=5) ;{ }^{*} \mathrm{p}<0.05$, compared with the control group; ${ }^{* *} \mathrm{p}<0.01$, compared with the control group.

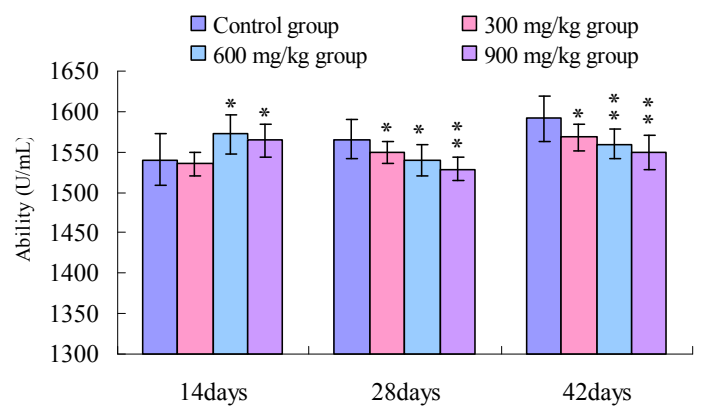

Figure 4. Change of the serum ability to inhibit hydroxy radical $(\mathrm{U} / \mathrm{mL})$ in broilers. Note: Data are presented with the means \pm standard deviation $(\mathrm{n}=5) ;{ }^{*} \mathrm{p}$ $<0.05$, compared with the control group; ${ }^{* *} \mathrm{p}<0.01$, compared with the control group.

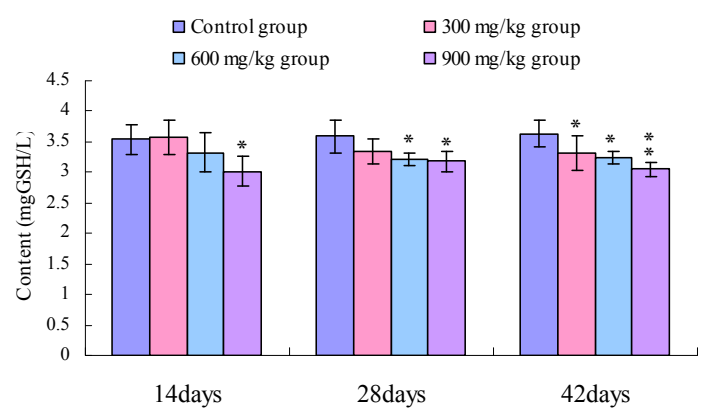

Figure 5. Change of the serum GSH content (mg GSH/L) in broilers. Note: Data are presented with the means \pm standard deviation $(\mathrm{n}=5) ;{ }^{*} \mathrm{p}<0.05$, compared with the control group; ${ }^{* *} \mathrm{p}<0.01$, compared with the control group. 


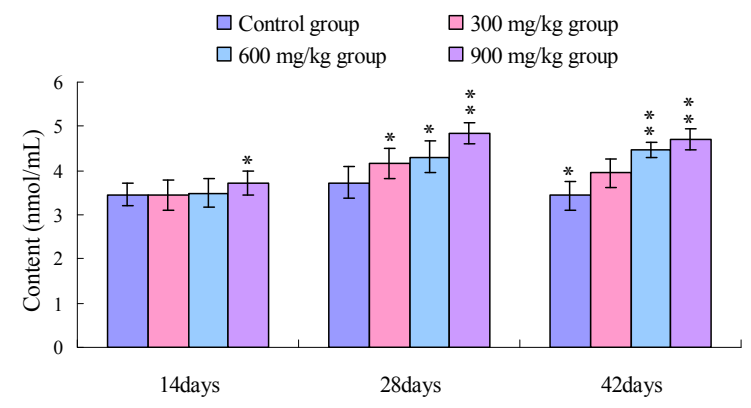

Figure 6. Change of the serum MDA content $(\mathrm{nmol} / \mathrm{mL})$ in broilers. Note: Data are presented with the means \pm standard deviation $(\mathrm{n}=5) ;{ }^{*} \mathrm{p}<0.05$, compared with the control group; ${ }^{* *} \mathrm{p}<0.01$, compared with the control group.

contents were increased in the $900 \mathrm{mg} / \mathrm{kg}$ at 14 days of age, and were markedly increased ( $\mathrm{p}<0.05$ or $\mathrm{p}<0.01$ ) in the $300 \mathrm{mg} / \mathrm{kg}, 600 \mathrm{mg} / \mathrm{kg}$ and $900 \mathrm{mg} / \mathrm{kg}$ groups from 28 to 42 days of age when compared with those of control group.

\section{DISCUSSION}

$\mathrm{Ni}$ and other heavy metals can generate free radicals directly from molecular oxygen in a two step process to produce superoxide anion. A data suggests that antioxidants may play an important role in abating some hazards of Ni [25]. A number of studies have demonstrated that $\mathrm{Ni}$ can enhance lipid peroxidation in the liver, kidney, lung, bone marrow and serum of rats, and dose-effect relationships for lipid peroxidation in some organs have also been observed [26-31]. Lipid peroxidation may be a contributing factor in Ni-induced tissue oxidative stress [28]. $\mathrm{NiCl}_{2}$ also induces lipid peroxidation in rat renal cortical slices in vitro (ATSDR) [32]. It has been reported that a single intraperitoneal injection of nickel acetate increased lipid peroxidation and glutathione-S-transferase activity in the liver and kidney of rats [33]. In agreement with the abovementioned researches, our data suggested that $\mathrm{NiCl}_{2}$ induced the serum oxidative stress in broilers, which showed a dose and time dependent increase of MDA contents, decrease of GSH contents and GSH-Px, SOD, CAT activities, and inhibit hydroxy radical in the serum.

The cumulative production of reactive oxygen species/reactive nitrogen species ROS/RNS through either endogenous or exogenous insults is termed oxidative stress [21]. Endogenous antioxidants have the capability to prevent the uncontrolled formation of reactive oxygen negative ion. These antioxidants including CAT, GSH or mannitol provides the protection against the oxidative stress [34].

SOD and CAT, as the antioxidant enzymes, are considered to be the first line of cellular defense against oxidative damage [35]. In the present study, the activities of antioxidant enzymes including SOD, CAT and GSH-
Px in the serum were all decreased in the $300 \mathrm{mg} / \mathrm{kg}, 600$ $\mathrm{mg} / \mathrm{kg}$ and $900 \mathrm{mg} / \mathrm{kg}$ groups compared with those of the control group (Figures 1-3). The decreased activities of these enzymes can lead to an excessive availability of superoxide and hydrogen peroxide in biological systems, which in turn will generate hydroxyl radicals involved in the initiation and propagation of lipid peroxidation [36]. In our study, it was found that the ability to inhibit hydroxy radical was decreased in $300 \mathrm{mg} / \mathrm{kg}, 600$ and 900 $\mathrm{mg} / \mathrm{kg}$ groups when compared with that of the control group (Figure 4). Furthermore, hydroxy radical is one of the major oxygen radicals that can cause oxidative stress. Low level of antioxidants and high level of free radicals lead to the development of oxidative stress in the body.

Non-enzymatic antioxidants, such as GSH, play a primary role and regarded as an early biological marker of the oxidative stress [37]. In the present study, the GSH contents were significantly reduced in $300 \mathrm{mg} / \mathrm{kg}, 600$ $\mathrm{mg} / \mathrm{kg}$ and $900 \mathrm{mg} / \mathrm{kg}$ groups from 14 to 42 days of age (Figure 5). The reduced GSH was an important cellular antioxidant because of high intracellular concentration and also serves as a substratum of essential scavenger enzymes to maintain oxidative balance [38]. The decreased GSH-Px activity may also be due to the reduced availability of GSH in the present study.

As an end product of lipid peroxidation (LPO), MDA can cause cross-linking in lipids, proteins and nucleic acids $[36,39,40]$. And the MDA production induces alteration of membrane fluidity and increase of membrane fragility [41,42]. Moreover, MDA inhibits various enzyme reactions and exerts mutagenicity and carcinogenicity by forming DNA adducts [43]. Our results clearly showed increased MDA contents of the serum caused by dietary $\mathrm{NiCl}_{2}$ (Figure 6). As a late biomarker of oxidative stress, the increased production of MDA implies the enhancement of lipid peroxidation and accumulation of lipid peroxides in the body, which consequently reduces antioxidative function of the broilers.

According to the results observed in the present study and the aforementioned discussion, it is concluded that dietary $\mathrm{NiCl}_{2}$ in excess of $300 \mathrm{mg} / \mathrm{kg}$ can cause inhibition of antioxidant enzyme activities, enhancement of lipid peroxidation and accumulation of free radicals in the serum, which consequently induces oxidative stress and impairs the antioxidant function in broilers.

\section{ACKNOWLEDGEMENTS}

The study was supported by the program for Changjiang scholars and innovative research team in university (IRT 0848) and the Education Department and Scientific department of Sichuan Province (09ZZ017).

\section{REFERENCES}

[1] Grandjean, P. (1984) Human exposure to nickel. IARC 
Scientific Publications, 53, 469-485.

[2] Clarkson, T.W., Friberg, L., Nordberg, G.F. and Sager, P.R. (1988) Biological monitoring of toxic metals. Plenum Press, New York, 265-282. doi:10.1007/978-1-4613-0961-1

[3] Anke, M., Grun, M., Ditrich, G. and Hennig, A. (1974) Low nickel rations for growth and reproduction in pigs. In: Hoekstra, W.C., Suttle, J.W., Canther, H.E. and Mertz, W., Eds., Trace Element Metabolism in Animals-2, University Park Press, Baltimore, 715-717.

[4] Nielson, F.H., Myron, D.R., Guvand, S.H., Zimmerman, T.J. and Ollerich, D.A. (1975) Nickel deficiency in rats. The Journal of Nutrition, 105, 1620-1630.

[5] Afridi, H.I., Kazi, T.G., Kazi, N.S., Kandhro, G.A., Baig, J.A., Shah, A.Q., Wadhwa, S.K., Khan, S., Kolachi, N.F., Shah, F., Jamali, M.K. and Arain, M.B. (2011) Evaluation of status of cadmium, lead, and nickel levels in biological samples of normal and night blindness children of age groups $3-7$ and 8 - 12 years. Biological Trace Element Research, 142, 350-361. doi:10.1007/s12011-010-8796-9

[6] Phipps, T., Tank, S.L., Wirtz, J., Brewer, L., Coyner, A., Ortego, L.A. and Fairbrother, A. (2002) Essentiality of nickel and homeostatic mechanisms for its regulation in terrestrial organisms. Environmental Reviews, 10, 209261. doi:10.1139/a02-009

[7] Stangl, G.I. and Kirchgessner, M. (1996) Nickel deficiency alters liver lipid metabolism in rats. The Journal of Nutrition, 126, 2466-2473.

[8] Nielsen, F.H., Uthus, E.O., Poellot, R.A. and Shuler, T.R. (1993) Dietary vitamin B12, sulfur amino acids, and oddchain fatty acids affect the responses of rats to nickel deprivation. Biological Trace Element Research, 37, 1-15. doi:10.1007/BF02789397

[9] Uthus, E.O. and Poellot, R.A. (1997) Dietary nickel and folic acid interact to affect folate and methionine metabolism in the rat. Biological Trace Element Research, 58, 25-33. doi:10.1007/BF02910663

[10] Friedrich, C.G., Schneider, K. and Friedrich, B. (1982) Nickel in the catalytically active hydrogenase of Alcaligenes eutrophus. Journal of Bacteriology, 152, 42-48.

[11] Friedrich, B., Heine, E., Finck, A. and Friedrich, C.G. (1981) Nickel requirement for active hydrogenase formation in Alcaligenes eutrophus. Journal of Bacteriology, 145, 1144-1149.

[12] Costa, M., Salnikow, K., Cosentio, Z., Klein, C.B., Huang, X. and Zhuang, Z. (1994) Molecular mechanism of nickel carcinogenesis. Environmental Health Perspectives, 102, 127-130.

[13] Kasprazak, K.S., Bal, W. and Karaczyn, A.A. (2003) The role of chromatin damage in nickel induced carcinogenesis. A review of recent developments. Journal of Environmental Monitoring, 5, 183-187. doi:10.1039/b210538c

[14] LaBella, F.S., Dular, R., Lemon, P., Vivian, S. and Queen, G. (1973) Prolactin secretion is specifically inhibited by nickel. Nature, 245, 330-332. doi:10.1038/245330a0

[15] LaBella, F.S., Dular, R., Vivian, S. and Queen, G. (1973) Pituitary hormone releasing or inhibiting activity of metal ions present in hypothalamic extracts. Biochemical and
Biophysical Research Communications, 52, 786-791. doi:10.1016/0006-291X(73)91006-1

[16] Yokoi, K., Uthus, E.O. and Nielsen, F.H. (2003) Nickel deficiency diminishes sperm quantity and movement in rats. Biological Trace Element Research, 93, 141-153. doi:10.1385/BTER:93:1-3:141

[17] Bencko, V. (1983) Nickel: A review of its occupational and environmental toxicology. Journal of Hygiene, Epidemiology, Microbiology, and Immunology, 27, 237-247.

[18] Ragsdale, S.W. (2006) Nickel enzymes and cofactors. In: King, R.B., Ed., Encyclopedia of Inorganic Chemistry, John Wiley \& Sons Ltd., New York, 3378-3393. doi:10.1002/0470862106.ia149

[19] Demir, T.A., Işıklı, B., Ürer, S.M., Berber, A., Akar, T., Canbek, M. and Kalyoncu, C. (2005) Nickel exposure and its effects. Biometals, 18, 7-13. doi:10.1007/s10534-004-1209-9

[20] Young, R.A. (1995) Toxicity Profiles. Toxicity summary for nickel and nickel compounds. http://risk.lsd.ornl.gov/tox/profiles/nickel

[21] Das, K.K., Das, S.N. and Dhundasi, S.A. (2008) Nickel, its adverse health effects \& oxidative stress. Indian Journal of Medical Research, 128, 412-425.

[22] Das, K.K. and Buchner, V. (2007) Effect of nickel exposure on peripheral tissues: Role of oxidative stress in toxicity and possible protection by ascorbic acid. Reviews on Environmental Health, 22, 133-149. doi:10.1515/REVEH.2007.22.2.157

[23] National Research Council (NRC) (1994) Nutrient requirements of poultry. 9th Edition, National Academy Press, Washington DC.

[24] Capcarova, M., Kolesarova, A., Arpasova, H., Massanyi, P., Lukac, N., Kovacik, J., Kalafova, A. and Schneidgenova, M. (2008) Blood biochemical dynamics and correlations in laying hens after experimental nickel administration. International Journal of Poultry Science, 7, 538547. doi:10.3923/ijps.2008.538.547

[25] Ercal, N., Gurer-Orhan, H. and Aykin-Burns, N. (2001) Toxic metals and oxidative stress part I: Mechanisms involved in metal induced oxidative damage. Current Topics Medicinal Chemistry, 1, 529-539. doi:10.2174/1568026013394831

[26] Coogan, T.P., Latta, D.M., Snow, E.T., Costa, M. and Lawrence, A. (1989) Toxicity and carcinogenicity of nickel compounds. Critical Reviews in Toxicology, 19, 341-384. doi:10.3109/10408448909029327

[27] Donskoy, E., Donskoy, M., Forouhar, F., Gillies, C.G., Marzouk, A., Reid, M.C., Zaharia, O. and Sunderman Jr., F.W. (1986) Hepatic toxicity of nickel chloride in rats. Annals of Clinical and Laboratory Science, 16, 108-117.

[28] Chen, C.Y., Sheu, J.Y. and Lin, T.H. (1999) Oxidative effects of nickel on bone marrow and blood of rats. Journal of Toxicology and Environmental Health-Part A, 58, 475-483. doi:10.1080/009841099157106

[29] Sunderman Jr., F.W., Marzouk, A., Hopfer, S.M., Zaharia, O. and Reid, M.C. (1985) Increased lipid peroxidation in tissues of nickel chloride-treated rats. Annals of Clinical and Laboratory Science, 15, 229-236. 
[30] Janicka, K. and Cempel, M. (2001) Lipid peroxidation and selected antioxidants in rat liver after oral exposure to nickel (II) chloride. Bromatologia i Chemia Toksykologiczna, 34, 291-295.

[31] Athar, M., Hasan, S.K. and Srivastava, R.C. (1987) Evidence for the involvement of hydroxyl radicals in nickel mediated enhancement of lipid peroxidation: Implications for nickel carcinogenesis. Biochemical and Biophysical Research Communications, 147, 1276-1281. doi:10.1016/S0006-291X(87)80208-5

[32] Agency for Toxic Substances and Disease Registry (ATSDR) (2005) Toxicological profile for Nickel. Department of Health and Human Services, Public Health Service, Atlanta, 95-107.

[33] Misra, M., Rodriguez, R.E. and Kasprzak, K.S. (1990) Nickel induced lipid peroxidation in the rat: correlation with nickel effect on antioxidant defense systems. Toxicology, 64, 1-17. doi:10.1016/0300-483X(90)90095-X

[34] M'Bemba-Meka, P., Lemieux, N. and Chakrabarti, S.K. (2005) Role of oxidative stress, mitochondrial membrane potential, and calcium homeostasis in nickel sulphateinduced human lymphocyte death in vitro. ChemicoBiological Interactions, 156, 69-80. doi:10.1016/j.cbi.2005.07.004

[35] Ferreccio, C., Gonzalez, P.C., Milosavjlevic, S.V., Marshall, G.M. and Sancha, A. (1998) Lung cancer and arsenic exposure in drinking water: A case control study in northern Chile. Cadernos de Saude Publica, 14, 193-198. doi:10.1590/S0102-311X1998000700021

[36] Halliwell, B. and Chirico, S. (1993) Lipid peroxidation: Its mechanism, measurement, and significance. American Journal of Clinical Nutrition, 57, 715-724.
[37] Gagliano, N., Dalle, D.I., Torri, C., Migliori, M., Grizzi, F., Milzani, A., Filippi, C., Annoni, G., Colombo, P., Costa, F., Cava, G.G., Bertelli, A.A.E., Giovannini, L. and Gioia, M. (2006) Early cytotoxic effects of Ochratoxin A in rat liver: A morphological, biochemical and molecular study. Toxicology, 225, 214-224. doi:10.1016/j.tox.2006.06.004

[38] Aw, T.Y. (2005) Intestinal glutathione: Determinant of mucosal peroxide transport, metabolism, and oxidative susceptibility. Toxicology and Applied Pharmacology, 204, 320-328. doi:10.1016/j.taap.2004.11.016

[39] Freeman, B.A. and Crapo, J.D. (1982) Biology of disease: Free radicals and tissue injury. Laboratory Investigation, 47, 412-426.

[40] Flohe, L., Beckmann, R., Giertz, H. and Loschen, G. (1985) Oxygen-centered free radicals as mediators of inflammation. In: Sies, H. Ed., Oxidative Stress, Academic Press, New York, 405-437.

[41] Janero, D.R. (1990) Malondialdehyde and thiobarbituric acid-reactivity as diagnostic indices of lipid peroxidation and peroxidative tissue injury. Free Radical Biology and Medicine, 9, 515-540.

doi:10.1016/0891-5849(90)90131-2

[42] Chen, J.J. and Yu, B.P. (1994) Alteration in mitochondrial membrane fluidity by lipid peroxidation products. Free Radical Biology and Medicine, 17, 411-418. doi:10.1016/0891-5849(94)90167-8

[43] Marnett, L.J. (1999) Lipid peroxidation-DNA damage by malondialdehyde. Mutation research, 424, 83-95. doi:10.1016/S0027-5107(99)00010-X 